\title{
PENENTUAN VANADIUM SECARA SPEKTROFOTOMETRI FOSFOWOLFROVANADAT DALAM BATUAN BUKIT PIANGGU KABUPATEN SOLOK
}

\author{
Roswita $^{1,2}$, Hamzar Suyani ${ }^{2}$ dan Safni ${ }^{2}$ \\ ${ }^{1}$ SMAN 1 Kubung Kabupaten Solok \\ ${ }^{2}$ Program Studi Kimia Pasca Sarjana Universitas Andalas Padang
}

\begin{abstract}
A simple, rapid and accurate Spectrophotometric method described to the determination of vanadium in ore using sodium tungstat as a complexing agent. The method is based on the oxidation of sodium tungstat to form a yellow colored on reaction with vanadium (V), having maximum an absorption occurred at $403 \mathrm{~nm}$. The relative standar deviation of the method for 8 $\mathrm{mg} / \mathrm{L}$ vanadium $(\mathrm{n}=11)$ was $0.24 \%$, and the molar absorptivity is $2.026 \times 10^{3} \mathrm{~L} \mathrm{~mol}^{-1} \mathrm{~cm}^{-1}$ and sensitivity Sandell is $2.5 \times 10^{-2} \mathrm{mg} \mathrm{cm}^{2}$. The recovery test is $99.47 \%$. The effect of ion interfering $\mathrm{Fe}$ (element large amount in ore) on determination is describe. The general procedure which was developed is suittable for determination of $0-20 \mathrm{mg} / \mathrm{L}$ of Vanadium and should be applicable to variety of ore sample.
\end{abstract}

Keywords : vanadium, spectrophotometric, sodium tungstat, ore

\section{DAFTAR PUSTAKA}

1. R. S. Young, Chemical Analysis in Extractive Metallurgy, Griffin, London, 1971, 220-222.

2. T. N. Kumar, and H. D. Revanasiddappa, Spectrophotometric Determination of Vanadium Using Variamine Blue and its Applycation to Syntetic, Environmental and Biologycal samples, Iran.Chem., 2: 161-167, (2005).

3. U. Repinc, and L. Benedik, Determination of Vanadium In Dietary Suplements, Acta Chim., 51: 59-65, (2005).

4. D. W. Hastings, and S. R. Emerson, Determination of Picogram Quantities of Vanadium In Calcite and Seawater by Isotope Dilution Inductively Coupled Plasma Mass Spectrometry With Electrothermal Vaparization, Anal. Chem., 68: 371-377, (1996).

5. L. Yang, R. E. Sturgeon, D. Prince, and S. Gabos, Determination of Vanadium In Biologycal Fluids Using HR-ICP-MS, Anal. At. Spect., 17: 1300-1303, (2002).
6. G. Telep, and D. F. Boltz, Ultraviolet Spectrophotometric Determination of Vanadium, Anal. Chem., 23: 901-903, (1951).

7. Y. Nakamoto, T. Ishimaru, N. Endo, and K. Matsusaki, Determination of Vanadium in Heavy Oils by Atomic Absorption Spectrometry Using a Graphite Furnace Coated with Tungsten, Anal. Sci., 20: 739-741, (2004).

8. N. Acnihotri, R. Dass, and R. Mehta, A Highly Sensitive and Selective Spectrophotometric Determination of Vanadium(V) Using 6-Chloro-3Hydroxy-7-methyl-2-(2-thienyl)- $4 \mathrm{H}-$ chromen-4-One, Anal. Sci., 15: 12611264, (1999).

9. R. Lobinski, and Z. Marczenko, Flotation-Spectrophotometric of Vanadium with 3,5-Dinitrocatechol and Rhodamine B, Anal.Sci., 4: 629-635, (1988).

10. A. M. Shiller, L. Mao, and J. Cramer, Determination of Dissolved Vanadium in Natural Waters by Flow Injection Analysis with Colorinetric Detection, Limnol. Oceanodr., 43(3): 526-529, (1998). 
11. R. A. Day, and A. L. Underwood, Analisa Kimia Kuatitatif, terjemahan A. H Pudjaatmaka, 5, Erlangga, Jakarta, 1999.

12. A. I. Vogel, Kimia Analisis Kuantitatif Anorganik, terjemahan A. Hadyana dan L. Setiyono, 4, EGC, Jakarta, 1994.

13. Harmita, Petunjuk Pelaksanaan Validasi Metode dan Cara Perhitungannya,
Majalah Ilmu Kefarmasian, 1(3): 117135, (2004).

14. Anonim, Sebaran Deposit Bahan Tambang pada kecamatan IX Koto Sungai Lasi, Gunung Talang, Pantai Cermin, dan Lembah Gumanti Kabupaten Solok, Dinas Pertambangan dan Lingkungan Hidup, Solok (2004). 